\title{
A renovação do registro das marcas de indústria ou comercio (*)
}

\author{
Constantino de Campos Fraga
}

\section{CONCEITOS PRELIMINARES}

1. Quando Vivante analizou a monumental obra de KoHler, um dos maiores méritos que nela assinalou, ao lado do vigor sistemático, foi a messe de princípios estatuidos pelo comercialista teuto, princípios estes "capazes de defender energicamente a atividade comercial, contra a con-

\section{(*) FUNDAÇAO PREMIO “CARVALHO DE MENDONÇA"}

Três alunos da cadeira de direito comercial do curso de bacharelado candidataram-se, em igualdade de condições ao Prêmio "Carvalho de Mendonça", de 1941: Egberto. Lacerda Teixeira, João Pedro da Veiga Pacheco e Constantino de Campos Fraga. Sorteada, da lista de teses, aprovada pela Congregação dos Professores da Faculdade de. Direito, nos termos do $\S 1$ do art. 11 dos estatutos da fundação, a epigrafada "A. renovação do registro das marcas de indústria ou comércio", apresentaram os três, no. nesmo dia que lhes fôra marcado, as suas dissertações sobre ela.

Justificam os três trabalhos, realmente, as notas distintas por eles alcançadas nos: exames finais da matéria, nos três anos do curso. Exposiçōes metódicas e serenas. Segura indagação legislativa, doutrinária e jurisprudencial sobre assunto relevante, que a escassez de tempo não permitiu lhes fosse explicada, senão referencialmente. Houveram-se, não obstante, com galhardia. Para ter idéia de como examinaram a. matéria, no particular e no geral, basta percorrer o sumário de cada dissertação. Por coincidênciă, cada qual dividiu a sua em onze capitulos, um, mais sucintamente, João. Pedro da Veiga Pacheco, em poucas páginas. Estendeu-se a de Constantino de Campos. Fraga por quarenta e sete, afóra as de transcriçōes de julgados. Mais do dobro, setenta e ôito, ocupou a de Egberto Lacerda Teixeira. Em verdade, nem sempre o maior número de páginas condiz com o merecimento do trabalho jurídico. Tal entret\&nto na hipótese não aconteceu. Se as duas últimas monografias revelam senso. jurídico e de investigação doutrinária, suplantando, mesmo, pelo vigor e coragem da. afirmação doutrinária, muitas das dissertações ultimamente apresentadas aos concursos de livre docência, a de Egberto Lacerda Teixeira lhe confere direito ao Prêmio "Car-. valho de Mendonça”, de 1941. E' ela, sem dúvida, a melhor das três, pela maior amplitude panorâmica do problêma, visto por ângulo mais largo. 
corrência desleal" (1). Anos depois, quando Alfredo Rocco se referiu à atividade magistral de Vivante no domínio do direito comercial, destacou, dentre as excelências de sua obra, "o mérito de ter formulado com precisão e haver fielmente seguido o preceito que põe, como base de todo o tratamento jurídico no campo do direito comercial, o estudo da estrutura econômica e técnica dos institutos" (2).

O exemplo dos mestres não deve ser deslembrado. Se desejamos bem apreender o conteudo de um organismo do direito comercial, se queremos chegar ao conhecimento intimo da engrenagem legislativa e judicial que o rege, faz-se mistér, além dos conhecimentos jurídicos, a observação atenta da realidade econômica.

Esta tem sido a orientação de nossos homens de govêrno, desde ha varios lustros, perfilhando uma tradição de cunho realísta e patriótico, sempre mantida no correr de nossa existência como nação.

Já em 1875 a Comissão de Justiça Criminal da Câmara dos Deputados se norteava pela necessidade de proteger a indústria desabrochante (3), afirmando mais tarde as Ses-

\footnotetext{
Não lhe fica muito distanciada a de Constantino de Campos Fraga. Reunem-se nela tantas qualidades, que bem merece menção especial.

Sem entrar na crítica das doutrinas desenvolvidas e sustentadas pelos candidatos, os professores catedráticos da disciplina e diretores da fundaçāo, são de parecer:

a) que o Prêmio "Carvalho de Mendonça" seja conferido ao melhor estudante de direito comercial do curso de bacharelado do triênio de 1939 a 1941, da Faculdade de Direito de São Paulo: o sr. Egberto Lacerda Teixeira. Consistirá o prêmio em diploma, expedido pelo exmo. sr. Diretor, è a ser entregue solenemente, em Congregação : num cheque de mil e quinhentos cruzeiros e numa coleção, encadernada, do "Tratado de Direito Comercial Brasileiro", do saudoso patrono da fundação, cujos nome e obra jurídica ela consagra e perenemente rememora;

b) que, em consideração pelo merecimento da dissertação do sr. Constantino de Campos Fraga, lhe seja conferido, na mesma Congregação, o diploma de menção honrosa.

Em Congregação dos Professores da Faculdade de Direito da Universidade de São Paulo, aos 30 de novembro de 1942.
}

(1) Vivante, "Trattato di Diritto Commerciale", p. 29, n. ${ }^{\circ} 860$, nota 16 , vol. $3 .^{\circ}, 5 .^{\mathrm{a}}$ ed. reimpressa em Milão, 1935.

(2) "Principios de Direito Comercial", p. 79, n. ${ }^{\circ} 18$, tr. C. DE Moncada, S. Paulo, 1931.

(3) Parecer da Comissão de Justiça Criminal da Câmara dos Deputados, 19/3/1875, in BENTo DE FARIA - Marcas dę fábrica e nome comercial, p. 35, n. 8 - Rio, 1906. 
sões reunidas no Conselho de Estado, ser "ao desenvolvimento dos recursos nacionais que o legislador deve principalmente atender" (4).

No decurso de nossas indagações, teremos sempre em vista os reflexos econômicos das diversas doutrinas que porventura analizarmos, sendo este um dos critérios aferidores de sua maior ou menor valia no quadro das realidades econômicas.

2. Este mesmo cunho realista, deve nos auxiliar no exame cuidadoso dos conceitos emitidos pelos grandes comercialistas, os quais, quando escreviam, nem sempre tinham em vista situação jurídico-econômica semelhante à nossa.

Não podemos desprezar o tesouro imenso de experiência científica acumulado nas páginas dos luminares do direito comercial. "A experiência alienígena é semelhante ao mapa de uma região que ainda estamos a explorar", disse Z. Chafee JR., e como tal deve ser aproveitada (5).

Não esquecendo, portanto, de observar as coisas "brasileiramente", dentro de nosso sistema jurídico, amoldado ao nosso meio econômico, estaremos aptos a tirar todo proveito da ciência estrangeira, sem corrermos o risco de crear teorias como castelos no ar, sem apôio em nossa realidade jurídico-econômica.

3. Teremos sempre em mãos a jurisprudência de nossos tribunais, a qual, se hesitante e relativamente escassa na matéria que nos preocupa, nem por isso deixa de ser fonte riquíssima de ensinamentos. E' nela que observamos a luta das teorias que procuram se adaptar às necessidades econômicas, ora satisfazendo-as, dando-nos a impressão de um instituto juridico que atinge plenamente a sua finalida-

(4) Sessões reunidas do Conselho de Estado, in Afonso Celso (Ouro Preto) - Marcas industriais e nome comercial, p. 22, n. ${ }^{\circ}$ 13 - Rio, 1888.

(5) Zechariah Chafee JR. - Unfair competition, in Harvard Law Reviev, p. 1.321, vol. $53-1940$. 
de, ora debatendo-se em acórdãos dissidentes, em recursos: inextinguiveis, fazendo saltar a nossas vistas a realidade econômica que se revolta contra a roupagem que se lhe quer ajustar.

\section{AS MARCAS DE INDÚSTRIA E COMERCIO - SUAS FUNÇбES}

1. Dentre os diversos institutos de direito comercial, é sem dúvida o das marcas de indústria e comércio daqueles. que mais intimamente ligados se acham ao desenvolvimento econômico da sociedade, nele poderosamente influindo.

"A marca é a concretização do crédito mercantil e industrial: a reputação do negociante ou do produtor materializada num emblema visivel", disse magnificamente Rur Barbosa (6).

As funções da marca são várias, decorrendo de sua natureza e não unicamente do carater que porventura lhe atribua tal ou tal outra lei. Assim, não é sua função exclusivamente "assinalar os produtos industriais e os artigos do comércio, distinguindo-os de outros de procedência ou origem diversa", como diz Gama Cerqueira ser a noção decorrente de nossa legislação (7). Mesmo que a lei não o declare, exerce a marca funções outras de suma importância, decorrentes de sua própria razão de ser, das necessidades econômicas que é chamada a satisfazer.

Primariamente, tem a marca por função identificar o produto, indicando-lhe a proveniência. Disse Vivante, no estilo elegante que lhe é peculiar, servir a marca para trazer ao comerciante "il merito o la colpa del suo lavoro, come la spola lanciata dal tessitore che gli riporta tessendo i frutti della sua fatica" (8).

(6) “As cessões de clientela”, p. 75, n. 54, Rio, 1913.

(7) "Marcas de Fábrica”, vol. II, p. 40, n.²3, S. Paulo, 1930.

(8) Ob. cit., vol. $3 .^{\circ}$, p. 28, n. ${ }^{\circ} 858$. No mesmo sentido Poulllet, "Marques de frabrique", p. 14, n. 5, Paris, 1898; Bosro, "Marchi e segni distintivi, p. 309, n. 154, Turim, 1904; Vivante, ob. cit., vol. $3 .^{\circ}$, p. 31, n. ${ }^{\circ} 863$. 
Identificando a mercadoria com seu autor, é a marca uుma garantia de sua reputação, um meio de lhe assegurar a própria clientela. Daí a função de "coletor de clientela", de auxiliar preciosa do industrial no bom êxito da atividade econômica. Tal é sua importância, que um dos mais recentes tratadistas italianos sobre a matéria, GHIRoN, chega a afirmar consistir a "verdadeira função da marca... na sua "opera penetratice" junto ao público, ação com a qual se apressa o processo de formação da clientela" (9).

Mas, não termina aí o papel da marca na ordem econômica. Tendo auxiliado a conseguir a clientela, ela impede que os indivíduos acostumados a confiar em determinada marca, símbolo de um bom produto, sejam enganados, vindo a adquirir mercadorias inferiores, de outros fabricantes que usem do mesmo sinal distintivo. E' a marca uma arma contra a concorrência desleal, uma barreira à ação do industrial ou comerciante sem escrúpulos (10).

"O orbe sedento quer cerveja, não explanações", disse numa decisão judicial LoRd Macnaughter (11). Mas, é preciso que compre a cerveja que realmente pensa comprar. A marca é uma garantia, não só para o produtor, como tambem, e em grande parte, para o consumidor. Ela impede que o comprador incáuto, ou impossibilitado de conhecer à primeira vista a qualidade do produto, devido à própria natureza deste, seja enganado em sua bôa fé. Permite-lhe que confiando num símbolo externo adquira a mercadoria que deseja, da qualidade que lhe convém.

Ora, um símbolo que identifica um produto, assegura a clientela, impede a concorrência desleal, impossibilita a

(9) “Corso di Diritto Industriale", p. 8-9, $\$ 77,2 .^{\circ}$ vol., Roma, 1937.

(10) "A marca... é como que uma barreira levantada ao redor do produtor... para impedir que outrem invada, de qualquer maneira, seu campo de atividade", Carneluttr, "Diritto al marchio e registrazione", n. 7 , p. 345, de "Rivista del Diritto Commerciale", vol. 10, parte 2.", Milão, 1912.

(11) Montgomery y. Thompson, (1891) A. C. 217, 225 - "Harvard Law Review", p. 1.297, vol. 53, 1940. 
fráude aos consumidores, tem evidentemente interesse para a coletividade. "Si a prosperidade dos Estados depende da plena segurança e máximo desenvolvimento da iniciativa privada, nenhuma instituição merece mais o patrocínio da lei do que a das marcas industriais", disse Ouro Preto (12). E, faz-lhe éco toda a corrente dos comercialistas, não só pátrios, como alienígenas, acordes em ressaltar o muito que ha de interesse geral na proteção às marcas de indústria $\mathrm{e}$ comércio (13).

2. Tendo ainda ante os olhos o quadro das funçöes exercidas pela marca, não nos devem surpreender as diferenças que encontrarmos entre a tutela jurídica destas e a que ampara o seu instituto vizinho, as patentes de invenção.

Com efeito, bem diversa é a situação. De um lado temos um símbolo que de tal maneira adere ao produto que qualifica, que a ele se incorpora, formando um tôdo indivisivel aos olhos do público acostumado a associar a mercadoria à marca que a caracteriza. E' uma creação do produtor, fruto de seu trabalho, em cuja conservação e defesa têm interesse não só ele como toda a sociedade.

Doutra parte encontramos um direito de exceção, incentivando inventores por meio de um privilégio que é contra a natureza dos bens creados, e que por isso mesmo é, e não poderia deixar de ser, provisório. "A regra geral do direito" diz o célebre juiz Brandeis, "é que as mais nobres produções humanas - conhecimentos, verdades inegáveis, concepções, e idéias - se tornem, depois de comunicações vo-

(12) Ob. cit., p. 45, n. 32 .

(13) Ascarelli, "Istituzioni di Diritto Commerciale", p. 47, n. 4, Milão, 1938; Vivante, ob. cit., p. 23-24, n. $856,3 .{ }^{\circ}$ vol. e p. 29-30, n. ${ }^{\circ} 861$, ob. e vol. cit.; Carvalho de Mendoça, "Tratado de Direito Comercial", p. 240-241, n..$^{\circ} 24$, - vol. $5 .^{\circ}, 1 .^{\text {a }}$ parte, Rio, 1919, e p. 242, n..$^{\circ} 225$, vol. cit.; Carlos da Silva Costa, Parecer in Apelação n. 6.937, Supremo Tribunal, "Razões da Apelante". p. 364, S. Paulo, 1940. 
luntárias aos demais, livres como o ar, para serem por todos usadas" (14).

Daí o efeito diverso do correr dos anos quanto ao direito às marcas de indústria e comércio e às patentes de invenção. Enquanto as primeiras se consolidam de dia para dia, as segundas vêm o têrmo de seu direito se aproximar, inexoravel, com o fluir do tempo.

Este reparo se fazia necessario, para que ao analizarmos os característicos do registro das marcas de indústria e comércio, e sua renovação, não nos impressionem comparações por ventura feitas com o registro das patentes de invenção.

REGISTRO DAS MARCAS DE INDÚSTRIA E COMERCIO, SUA FUNÇÃO. REGISTRO DECLARÁTIVO E REGISTRO ATRIBUTIVO

1. Sendo a marca instituto de suma relevância para o progresso e segurança econômicos, não poderia o legislador deixar de lhe dar amparo jurídico. Daí o registro, comprovante de que "determinado sinal se tornou de uso exclusivo daquele que o destina para assinalar o produto que manufatura ou a mercadoria que negoceia" (15). Tem ele por finalidade, disciplinando o uso das marcas, garantir o produtor, o comerciante e o público contra os abusos da má fé e da concorrência inescrupulosa.

$\mathrm{E}^{\prime}$ pelo registro que o comerciante ou industrial adquire o direito ao uso exclusivo da marca, direito esse em que repousa não poucas vezes sua fortuna. Permitir que ôutrem o viole, que terceiro aponha em mercadorias diversas a marca que lhe pertence, é dar mãos à pirataria comercial,

(14) International News Service v. Associated Press, 248, U. S. at 250 (1918) in "Harvard Law Review", vol. 53, p. 1318, 1940. No mesmo sentido, entre outros, Invrea, "Dizionario pratico del diritto privato" de V. ScraloJa, voc. "Marchi di fabbrica", vol. III, p. 808 , ed. Valardi.

(15) Carvalho de Mendonça, ob. e vol. cit., p. 315, n. 278. Neste estudo usaremos a palavra "registro" no sentido amplo que lhe assinala o grande mestre brasileiro, abrangendo o depósito $\mathrm{e}$ sua publicidade oficial. 
à rapinagem econômica da pior espécie, a qual em pouco lempo, pela insegurança acarretada, trará prejuizos inestimaveis ao comércio e à indústria.

Por isso a legislação de paises de grande desenvolvimento industrial, como os Estados Unidos, torna-se cada vez mais rigorosa, quotidianamente ampliando o campo de ação das marcas, apertando cada vez mais os aneis constrictores das leis que procuram sufocar a serpe nefasta da concorrência desleal. Na doutrina norte-americana vigorosamente repercute a orientação legislativa, afirmando ChafeE $J_{R}$. que, "quanto mais amplia o Congresso o ráio de ação do registro, incluindo símbolos que não costumavam ser considerados técnicamente como marcas, menores se tornam os perigos de uma zona propícia às cavilações do comércio "desleal" (16).

Registrar u’a marca é garantir o próprio direito, e ao mesmo tempo contribuir para o desenvolvimento econômico da nação. Esta a finalidade do registro.

2. Mas, o registro se limita a amparar um direito preexistente, ou é ele quem dá origem à propriedade sôbre a marca? Este é um dos mais tormentosos problemas que desafiam a argúcia do estudioso das marcas de indústria e comércio, em cuja solução divergem a doutrina e jurisprudência, tanto estrangeiras quanto pátrias.

a) Se pedirmos luzes à pleiade ilustre de comercialistas que se ufana de pertencer ao país que maior incremento deu aos estudos de direito comercial, à Italia, desde

(16) Ob. cit., rev. cit., p. 1301. Quanto aos caracteristicos do registro; Waldemar Ferreira, Parecer no caso Malzbier, Apelação civel, $n .^{\circ}$ 6.864, Razões da ré, p. 131, n..$^{\circ}$, Rio, 1938; Conselheiro Andrade Pinto, voto divergente na Consulta das Secçóes reunidas dos Negócios do Império e da Justiça do Conselho de Estado, 1884, in Ouro Preto, ob. cit., p. 266; Gama Cerqueira, ob. e vol. cit., p. 287, n. 198; Braun, Bissot e Favart, "Précis des marques de fabrique et de commerce", p. 127, n..$^{\circ} 89$, Bruxelas, 1936; CarnelutTr, ob. rev. cit., n. ${ }^{\circ} 19$, p. 360 ; Giovanni Fontana, "La disciplina della concorrenza negli Stati Uniti d'America", p. 65, Milão, 1937; VIVANTE, ob e vol. cits., p. 28 , n. 860 e p. 45 , n. 877 . 
logo nos resignaremos ao emaranhado das controvérsias que nesta matéria campeia, tanto no nosso quanto no direito italiano.

No início do século XIX expunha Bosio de maneira sedutora a doutrina do registro declarativo de direito: "Úma cousa é o direito, outra a formalidade de seu registro. Querer subordinar a existência daquele a esta, equivale a fazer reviver o antigo conceito que considerava o direito ao uso exclusivo generosa concessão do príncipe. Tambem a lei civil prescreve que, no prazo de cinco dias, todo nascimento deve ser comunicado e inscrito nos registros do estado civil. Mas, se por qualquer motivo, esta formalidade não é cumprida, será que aquele individuo, cujo nome não figura no livro do estado civil, não terá existência real nem personalidade ante a lei? Será lícito a qualquer pessôa espancá-lo, roubá-lo ou matá-lo? Da mesma maneira que o depósito não crea o direito, não o póde suprimir a falta dessa formalidade" (17).

Para Bosio, como para Vivante (18), Navarrini (19), e varios outros comercialistas, o registro não é atributivo da propriedade, a qual se adquire pelo uso da marca.

Carnelutti defendeu em interessante comentário de decisão judicial a teoria do direito à marca de natureza pessoal, doutrina típica do direito alemão, chegando, quanto à nossa matéria - o registro - , à mesma conclusão dos autores que vimos examinando. Para ele, o registro nada mais é que "una di queste debolezze del diritto al marchio" (20).

A doutrina do registro como formalidade meramente declarativa do direito, o qual se adquiriria pelo uso, mereceu

(17) Ob. cit., p. 337, n. 164.

(18) Ob. e vol. cit., p. 46, n. ${ }^{\circ} 878$ e 879.

(19) “Diritto Commerciale", p. 52-53; n. ${ }^{\circ}$ 1.445-bis, vol. IV, ed. Fratelli Bocca, 1920. No mesmo sentido, Grambrocono e Gozzano, “La Marca", p. 73, Milão, 1935.

(20) Ob. e rev. cit., n. ${ }^{\circ} 16$, p. 355. Aliás, já Vivante assinalára não levar a doutrina do direito pessoal a conclusões diversas da do direito pelo uso na esfera de nossas indagações. Cf., ob. e vol. cits., p. 29, n. 860 , nota 16 . 
a crítica de Brugi que a considera, em sua maior parte "una dottrina da fare" (21) ao mesmo tempo que o próprio VIvante se refere aos "insoluveis processos sobre a precedência no uso das marcas" (22).

Carnelutti é mais concludente quando em rápidas linhas sintetiza a teoria do registro atributivo de direito, do que quando expõe sua própria doutrina: “As normas já citadas subordinam ao registro a exclusividade do uso; mas, não há direito à marca sem faculdade de fazer dela uso exclusivo... O interesse de quem usa a marca é de que outros não a utilizem, isto é, não caracterizem suas mercadorias com a mesma marca, gerando a confusão que ela procura evitar, é portanto, interesse quanto ao uso exclusivo da marca. Este interesse torna-se direito desde que o garante a ordem jurídica; assim, a tutela da marca só pode consistir na garantia à exclusividade do seu uso" (23).

Defende ardentemente esta doutrina GHiron, para o qual o caracter do registro na nova lei italiana de 1935 é nitidamente atributivo, sendo-o tambem, apesar de menos pronunciadamente, na legislação anterior (24). Todavia, reconhece ele expressamente ser a matéria "controvertida, em doutrina e jurisprudência".

Outros escritores, baseados nas disposições do projeto da comissão nomeada em 1906 e na lei de 1935 sustentam um sistema mixto para a lei italiana. 0 registro possue uma primeira fase durante a qual se admitem oposições, consolidando-se depois o direito do titular da marca registrada que passará a não admitir impugnações. Assim, ha um primeiro período de registro declarativo, ao qual sucede o segundo, de registro atributivo (25).

(21) “Della Proprietà", p. 462-463, n. $97,2 .^{\circ}$ vol., Napoles,

(22) Ob. e vol. cits., p. $38, n .^{\circ} 871$.

(23) Ob. e rev. cits., n. ${ }^{\circ}$, p. 341-342.

(24) Ob. cit., p. $44, \S 86$, II, $20^{\circ}$ vol.

(25) Neste sentido: Parecer da "Commissione incaricata di redigere un progetto di legge sui marchi". Relator: CHIRONI. Resumo de Navarrini, ob. cit., pag. 62 , n. ${ }^{\circ} 1.450$, nota 4 , vol. IV; GiamBRocon e Gozzano, ob. cit., p. 81. Outros, baseados no art. 2 da lei 
b) Divergências de igual quilate encontraremos em nossa doutrina e jurisprudência (26).

Sustenta, entre outros, Carvalho de Mendonça, que entre nós não só no domínio das leis anteriores, como tambem no do vigente decreto $n .^{\circ} 16.264$, de 1923 , o registro "não é atributivo do direito de propriedade da marca, mas, simplesmente, declarativo desse direito. Ele não o cria; assegura, apenas, o direito de propriedade do utente da marca, tornando-o público e o prestigiando com favores especiais" (27). Carlos da Silva Costa quando sustentou o parecer dado no caso da marca "Radium", tambem foi explícito: "quer na vigência das leis anteriores, quer na da atual, o registro não é atributivo da propriedade, mas simplesmente declarativo dela".

Se são acordes os comercialistas pátrios em reconhecer ao registro no regime das leis de 1885, 1887, 1904 e 1905, o caracter declarativo do direito (28), esse consenso desaparece quando se trata do registro sob a lei vigente.

Waldemar Ferreira, defendendo a doutrina que vê no registro regulado pelo dec. 16.264 caracter atributivo do direito, expende argumentação que se enraiza profundamente na própria base de nosso sistema jurídico.

Vimos qual a função da marca e a razão da necessidade de seu registro. Facil nos será aquilatar o alcance da argumentação: "Não está nisso, nessa exclusividade, o direito de propriedade? Pois os direitos, que a lei assegura ao proprietário, nos termos do art. 524 do Código Civil, não

francesa de 1857 , sustentam a doutrina do registro "declarativo da propriedade, mas atributivo de todas as vantagens da lei especial". Cf. Navarrini, ob e vol. cit., p. $52, \mathrm{n} .^{\circ} 1.444$, nota 1 .

(26) Jurisprudência anexa, p.

(27) Parecer in Apelação n. ${ }^{\circ}$ 6.937, Supremo Tribunal, Razões da Apelada, p. 104, S. Paulo, 1940; "Tratado de Direito Comercial", p. 243, n. $.^{\circ} 26,5 .^{\circ}$ vol., $1 .^{a}$ parte e p. 291, n. ${ }^{\circ} 266$, ob. vol. e parte cits . Ha todavia uma hipótese na qual Carval Ho DE Mendonça reconhece efeito atributivo ao registro: é quando a marca não fốra anterıormente usada por outro comerciante ou industrial. Cf.: ob., vol. e parte cits., p. 351, n. $^{\circ} 327$.

(28) Bento de Faria, ob. cit., p. 234; Solidonio Leite, Parecer in Apelação n..$^{\circ}$ 6.537, Razões da Apelada, p. 8, S. Paulo, 1940. 
são, exatamente, os de usar, gozar e dispôr de seus bens, e o de rehavê-los do poder de quem quer que injustamente os possua? E não são esses, precisamente, os direitos que a lei garante ao comerciante ou ao industrial sôbre a marca que registrou?" (29). Pouco adiante conclue o eminente mestre: "O registro, só ele é que atribue ao proprietário da marca registrada os direitos inerentes à propriedade" $(30)$.

E' do mesmo pensar o insigne Clovis Bevilaqua, o qual dá como fontes de sua convicção, além do exame da doutrina pátria, o acurado estudo dos textos legislativos de 1904 e 1923, que mostram a orientação diversa de seus redatores. Gama Cerqueira vê no registro sob a atual lei de marcas o caracter atributivo de direito, explicando a oscilação que ainda hoje domina nossa doutrina e jurisprudência, como originada por reminiscências do sistema jurídico que regera a matéria, de 1885 a 1923 (31).

Estas as duas correntes que encontramos divergindo em nosso direito. Tendo conhecimento dos princípios gerais de que se originam, estamos habilitados a bem compreender a razão da discrepância dos comercialistas em face dos problemas suscitados pela renovação das marcas de fábrica, conforme se filiem a uma ou outra corrente.

\section{DURAÇAO DOS EFEITOS DO REGISTRO DA MARCA DE INDUSTRIA E COMÉRCIO}

1. E' da natureza do direito à marca, como já observamos, o tornar-se cada vez mais forte, mais vigoroso e firme com o correr dos anos. Desde que nasceu u'a marca, desde que ela existe, afirmou Pouillet, "basta usá-la para que se a conserve livre das pretenções de terceiros. Este uso

(29) Parecer no caso "Balança Howe", p. 33 de "Renovação do Registro de Marcas", S. Paulo, 1929.

(30) Parecer cit., p. 34. Cf. quanto à essência do direito de propriedade sobre a marca, do mesmo autor, Parecer no caso "Malzbier" in Apelação Civel n. ${ }^{\circ}$ 6.864, Razões da Ré, n. ${ }^{\circ}$ 1, p. 131, Rio, 1938.

(31) Ob. cit., p. 296, n..$^{\circ} 204$, nota 1, II vol. e p. 295, n. 204. 
ininterrupto, renova continuamente a apropriação e conserva o direito. Não se faz necessário ato ou declaração de qualquer espécie; o exercício do direito, exclusivamente, o perpetua e mantém intacto" (32).

Adquirida a propriedade da marca, ela se conserva indefinidamente, com a continuação do uso (33), é voz corrente entre os comercialistas. Nem poderia ser de outra maneira, uma vez que é função da marca, entre outras, o assinalar as mercadorias às quais é aposta. Enquanto estes produtos existirem no mercado, a marca tem uma finalidade a realizar, algo que poderíamos denominar "dever" a cumprir, não só para com o industrial ou comerciante seu proprietário, como em.relação ao mundo consumidor.

2. Se esta é a natureza do direito à marca, deveriam todas as legislações considerar perpétuo o registro, regularmente processado. Mas, só a Bélgica, Iugoslávia, Dantzig, Rússia e em parte o Canadá (34), podem ser enumerados entre as nações que atualmente adotam em seus textos de lei o registro de duração ilimitada.

Um rápido olhar pela nossa legislação nos descortinará a orientação do legislador pátrio:

Decreto n. ${ }^{\circ} 2.682$, de 23 de Outubro de 1875 (35)

ART. 13 - O efeito legal do registro durará por 15 anos, sendo o mesmo registro renovado, findo esse prazo, para que a propriedade exclusiva da marca seja mantida nos termos desta lei.

(32) Ob. cit., p. 116-117, n. 80 e p. 115, n. 79.

(33) Almeida Nogueira e Fischer JR. "Marcas Industriais", p. 109-110, n. ${ }^{\circ} 202,1 .^{\circ}$ vol., S. Paulo, 1910; Navarrini, ob. cit., p. 49, n. 1.443 , vol. IV.

(34) Braun, Bissot e Favart, ob. cit., p. 619, n. 560.

(35) “O Direito", p. 764, vol. 8 - 1875. - Afirma Solidonio LEITE ter sido esse dispositivo inspirado no Art. $3 .^{\circ}$ da lei francesa de 1857, que reza: “Le depôt n'a d'effet que pour quinze années. La propriété de la marque peut toujours être conservée pour un nouveau terme de quinze années au moyen d'un nouveau dépôt" C.f. Parecer in Apelação n..$^{\circ}$ 6.937, Supremo Tribunal, Razões da Apelada, p. 6, S. Paulo, 1940. 
Decreto n. ${ }^{\circ} 3.346$, de 14 de Outubro de 1887 (36)

ArT. 12 - O registro prevalecerá para todos os seus efeitos por 15 anos, findos os quais poderá ser renovado e assim por diante.

Decreto n. ${ }^{\circ} 1.236$, de 24 de Setembro de 1904 (37)

Art. 11 - O registro prevalecerá para todos os seus efeitos por quinze anos, findos os quais poderá ser renovado, e assim por diante.

Regulamento aprovado pelo Decreto $\mathrm{n}^{\circ} \mathrm{5.424}$, de 10 de Janeiro de 1905 (38)

ArT. 3 - O registro prevalecerá para todos os seus efeitos por quinze anos, findos os quais poderá ser renovado.

Decreto n. ${ }^{\circ}$ 16.264, de 1923

ART. 96 - O registro prevalecerá, para todos os ele1tos, por 15 anos, findos os quars poderá ser renovado e assim sucessivamente.

Qual o motivo deste contraste entre um direito que se diz perpétuo pelo uso e um registro temporário? A razão nos é dada pela doutrina da imensa maioria de paises que adotam um sistema, como o nosso, de registro temporário.

O registro, como tivemos oportunidade de salientar, tem por finalidade precípua dar a garantia necessária ao desenvolvimento sem entraves do comércio e indústria, pela eficaz proteção das marcas. Daí as penalidades rigorosas impostas aos infratores do direito por ele tutelado, penalidades que constituem a "norma de ferro" a que se referia no séc.

(36) “O Direito", p. 460, vol. $44-1887$.

(37) “O Direito", p. 550, vol. $95-1904$.

(38) “O Direito", p. 601, vol. 96 - 1905. 
XVIII o representante dos comerciantes de Burgos (39), como sendo a mais propícia ao desenvolvimento de um organismo econômico poderoso.

Mas, é preciso que este sistema jurídico férreo dê aos comerciantes a possibilidade de se acautelarem, evitando infrações imprevistas, de consequências as mais desastrosas. Por isso, sendo tão rigorosa a proteção à marca registrada, mistér se faz que o individuo que deseja registrar a insignia caracteristica de seu produto esteja em condições de saber com certeza se existe ou não marca semelhante anteriormente registrada.

Relativamente ao direito gaulês, disse Pouillet: "Quantas marcas depositará o comércio francês num dia, num ano? Não será consideravel o seu número? Qual será ele em cinco, vinte anos, num século?! E o comerciante será obrigado, sob pena de prisão ou multa, a consultar os registros feitos neste período! Quantas horas inutilmente gastas! Por melhor que seja a ordem de classificação, será ela tão metódica que não deixe escapar às mais cuidadosas pesquisas uma única marca? Tais foram as reflexões feitas pelo legislador, e, para facilitar as pesquisas, para não deixar pretexto algum aos contrafactores, limitou a quinze anos os efeitos do registro, deixando todavia ao depositante o direito de o renovar por um novo período de quinze anos, e, mediante renovações sucessivas, de o perpetuar. Que há de mais natural, prudente, sábio? Quanto ao interesse do fabricante, ele nada sofre - o demonstraremos - com a obrigação que se lhe impôs" (40).

A doutrina belga, pela voz autorizada de Braun, Bissot e Favart (41), vê no instituto da renovação do registro, a preocupação de "sanar o quadro das marcas", removendo periodicamente o entulho das marcas fracassadas, mortas pelo desuso e desinteresse de seus proprietários.

(39) Thaller, "De l'attraction exercée par le code civil et par ses méthodes sur le droit commercial, p. 233 do "Livre du Centenaire du Code Civil”, 1.० vol., Paris, 1904.

(40) Ob.-cit., p. 179-180, n. ${ }^{\circ} 131$.

(41) Ob. cit., p. 621, n. 563. 
O direito italiano, com sua recente lei de 1935 nos dá o espetáculo interessante de uma nação que, em nossos dias, abandonou o sistema do registro perpétuo, para adotar o do registro temporário. $\mathrm{E}$, se de um lado encontramos na doutrina italiana apôdos ao sistema anterior, críticas às suas falhas, por outro é unânime o regozijo pelo sistema inaugurado em 1935.

Vivante, que escrevera sob a lei anterior, qualificava de "deploravel" (42) o sistema por ela seguido. Ramella, em 1927 analizando a legislação alienígena, dá como motivo do registro de efeitos temporários o "não tornar ilusórios os benefícios da publicidade das marcas, o que aconteceria se, permanecendo elas indefinidamente inscritas, devessem as pesquisas necessárias ao seu conhecimento, abranger um dilatado período" (43).

Comentando um projéto de lei a ser submetido ao exame do legislativo italiano, inclue NAvarrini entre as louvaveis inovações nele contidas, o "evitar este inconveniente" (44) dos registros refertos de marcas de há muito sem valor.

Depois de 1935, Sebastianin a afirma estar "eliminado completamente esse grave inconveniente, estabelecendo a nova lei que a tutela da marca póde ainda conservar-se indefinidamente, mas para atingir este fim é necessário renovar o registro cada decênio" (45).

Ghiron, igualmente diz ser "a introdução do prazo assás oportuna e conforme ao que se pratica no exterior, porque libera os registros das marcas inúteis e torna mais expeditas

(42) Ob. cit., p. 51-52, n. $886,3 .^{\circ}$ vol.

(43) “Trattato della proprietà industriale", p. 125, n. $^{\circ} 497,2 .^{\circ}$ vol., Turim, 1927.

(44) Ob. cit., p. 509, Apendice, vol. IV.

(45) "Tutela delle privative industriali e dei marchi di fabbrica e di commercio", p. 93, Padua, 1936. Ressalta este autor o inconveniente existente no regime anterior, de se "subtrair perpetuamente à livre disposição do publico, pelo fato do registro", marcas que "não têm mais motivo de serem consideradas reservadas". Cf. loc. cit. 
as pesquisas sôbre registros anteriores, limitando as indagações aos do último decênio" (46).

Entre nós, como o folhear da legislação o patenteou, a tradição ininterrupta desde 1875 deu ao registro o carater transitório. $\mathrm{O}$ motivo do regime adotado no alvorecer de nossa legislação sobre marcas, e desde então continuamente seguido pelos nossos homens de leis, é o mesmo que deu preferência a este sistema nos demais paises do orbe civilizado.

Em 1888, Ouro Preto referia-se à crítica de Drdimo dA VEIGA, refutando-a baseado em RENDU, cujas palavras fazia suas: "a renovação do registro é uma das disposições mais lógicas da lei" (47). Carvalho de Mendonça, que, em seu monumental "Tratado de Direito Comercial", afirmara ser o escopo da lei "poupar aos terceiros, os embaraços que as longas buscas nos arquivos poderiam trazer para a verificação da legitimidade das marcas" (48), teve, em posterior parecer, oportunidade de reafirmar o seu pensar, pontificando visar a renovação do registro "o rejuvenescimento automático dos arquivos da propriedade industrial” (49), proporcionando "uma fonte informativa, breve e exata".

Não é diversa a opinião de Waldemar Ferreira, quando analiza a questão sob o prisma realista da função das marcas: "Verdadeiramente feliz é a marca que assinala o produto de tal geito que se torne impossivel desagregar uma do outro: a que esse resultado não produza, falha ao seu fadário. Nisso está a razão de ter-se restringido ao tempo de 15 anos, ressalvada a renovação do registro da marca, a sua proteção legal" (50).

(46) Ob. cit., p. $74, \S 91,2 .^{\circ}$ vol. No mesmo sentido: GIAMBrocono e Gozzano, ob. cit., ps. 90-91.

(47) Ob. cit., p. 70, n. 61 , nota 21.

(48) Ob. cit., p. 243-244, n. $.^{\circ} 226,5 .^{\circ}$ vol., 1. ${ }^{a}$ parte.

(49) Parecer in Apelação n. ${ }^{\circ} 6.937$, Supremo Tribunal, Razões da Apelada, p. 104/105, S. Paulo, 1940; mesmo parecer, p. 106.

(50) Parecer no caso "Malzbier", n..$^{14}$, p. 139 da Apelação Civel n.o 6.864 - Razões da Ré, Rio, 1938. Do mesmo sentir: JusTo; M. DE Moraes, Parecer in Apelação n..$^{\circ}$ 6.937, Supremo Tribunal, 
Decorre portanto da tradição legislativa e doutrinária, pacificamente vigente desde os primórdios do nosso direito sobre marcas, bem como do sentir conforme dos luminares do direito comercial alienígena, o consenso reinante na matéria, de que:

o único motivo pelo qual o registro de marcas de indústria e comércio tem duração temporária, é a conveniência de se aliviarem os repertórios dos registros, das marcas caducas (51).

Este conceito nos será de valia ao tentarmos solucionar a questão da oposição e do reexame da marca renovanda.

\section{NATUREZA JURfDICA DA RENOVAÇÃO DO REGISTRO DAS MARCAS DE INDUSTRIA E COMÉRCIO}

1. A renovação do registro das marcas de indústria e comércio constitue novo registro, ou é mera formalidade extrínseca, que em nada afeta o direito anteriormente adquirido?

Nesta pergunta está o ponto crucial do problema da renovação do registro, a chave para a solução das diversas questões que se nos apresentarão.

Divergem os comercialistas pátrios que cuidaram deste problema. Para uns, como Afonso Costa e Carlos da Silva Costa é a renovação um novo registro, para outros, entre os quais Carvalio de Mendonça, Clovis Bevilaqua e Waldemar Ferreira, é a renovação mera formalidade que em nada afeta o direito do proprietário do registro cujo prazo de proteção legal está prestes a expirar.

Razões da Apelada, p. 195-196, S. Paulo, 1940; Gama Cerqueira, ob. cit. p. 335-336, ns. 235 e 237 , II vol.

(51) Curiosa exceção a esta regra, faz a lei belga de 23 de Julho de 1932, a qual instituira a renovação por "finalidades fiscais" : Foi derrogada em 30 de Junho de 1933, e seu exemplo permaneceu sem imitadores. Cf. Braun, Bissot e Favart, ob. cit., p. 128, n. $^{\circ} 89$ bis. 
Baseiam-se os partidários da primeira corrente no fato de se repetirem na renovação as formalidades extrínsecas do registro, para daí concluirem tratar-se, no caso, de prazo de decadência de direito, e, consequentemente, de novo registro.

E' a argumentação de Carlos da Silva Costa (52), a qual chega à mesma conclusão de Afonso Costa: "os direitos que o registro conferiu ao proprietário da marca registrada têm duração restrita ao prazo de 15 anos, e embora o seu titular disponha da faculdade de renová-lo, este processo... deve obedecer às normas exigidas para o registro primitivo, cabendo à autoridade administrativa entrar não só no exame das formalidades extrínsecas, como no mérito do pedido quanto às objeções que se lhe possam fazer" (53).

Invoca-se em favor desta doutrina, entre os comercialistas estrangeiros, Ramella, e entre os nossos, Bento de Faria.

A opinião de Ramella, focalizando interessante prisma da renovação, não se aplica inteiramente ao caso em apreço. E' preciso forçarmos um pouco o sentido das palavras deste grande jurista, para chegarmos à conclusão que se lhe quer dar. Com efeito, depois de analizar o caráter perpétuo do direito à marca, contrastando-o com o direito sobre as patentes, passa Ramella a considerar o caso dos paises que adotam o registro temporário (escrevera ele na Italia de 1927), sem terem disposições legislativas que digam respeito à caducidade do mesmo, pelo desuso da marca: "Mas a renovação, como o registro originário, nada mais é que manifestação da vontade de usar e conservar o direito exclusivo sobre a marca, não implica por si mesma ato de posse, isto é, emprego comercial da marca, sem a qual a renovação não tem eficácia conservadora do direito. Se de outra maneira fosse, poderiam se entulhar os registros com renova-

(52) Parecer no Caso da marca "Radium", p. 92-93 da Apelação n..$^{\circ}$ 6.937, Supremo Tribunal, Razões da Apelada, S. Paulo, 1940.

(53) Voto em separado no Acórdão n..$^{\circ} 310$, de 9 de julho de 1935, do Conselho de Recursos da Propriedade Industrial, in Diário Oficial da União", de 24 de julho de 1935, p. 16.169. 
ções de marcas das quais não se faz uso, empecendo o livre comércio". Destas considerações, conclue em seguida: "A renovação, em si, pode ser considerada qual um novo depósito, pelo que o exame da marca quando prescrito, se regula pelo estado de fato e de direito que existe no momento da renovação" (54). Ora, evidentemente, este não é o caso da renovação entre nós vigente, nem ha melhor argumento que a própria lei:

ART. 115 - "Caducará o registo da marca, se qualquer interessado provar perante a Diretoria Geral da Propriedade Industrial que o respetivo proprietário deixou de fazer uso dela durante três anos consecutivos". (Dec. n. $\left.{ }^{\circ} 16.264\right)$.

Sublata causa, tollitur effectus.

O acatado parecer de Bento de FARIa é disputado pelas duas correntes, e a razão está no próprio texto do insigne mestre, o qual indubitavelmente se presta a interpretações divergentes.

Todavia, parece-nos mais consentânea com as premissas por ele assentadas a conclusão que faz do eminente comercialista um dos paladinos da renovação com caráter meramente conservatório de direito. "Os efeitos legais resultantes do registro da marca, escreve Bento dE FARIA, assinalando, em regra, a conservação do direito ao seu uso exclusivo, não têm duração indefinida. A proteção legal é apenas garantida durante um prazo certo e determinado. Essa limitação, fixada, aliás, no próprio interesse do industrial e do comerciante, funda-se na necessidade de facilitar a verificação do registo de marcas anteriores, para aceitação ou recusa da que fôr apresentada, ficando igualmente removido o grave inconveniente de obrigar a pesquizas por incalculável número de anos, afim de indagar si marca idêntica ou semelhante possue a prioridade das garantias pedidas

(54) Obra cit. pag. 127, n. ${ }^{\circ} 497,2 .^{\circ}$ vol. 
por aquela que é levada a registo. Não obstante, porém, fica salvo ao proprietário da marca o direito de, renovando sucessivamente o respetivo registro, perpetuar assim os seus efeitos. Da sua vontade, portanto, depende exclusivamente prolongar e manter a segurança da proteção legal" (55). Páginas adiante, afirma o eminente comercialista: “A renovação do registro deve ser feita da mesma fórma que o registro primitivo. $E$ ' portanto, um novo registro. Assim deve obedecer e cumprir as mesmas exigências e formalidades, e satisfazer igualmente as condições de publicidade". (56) Nas palavras de Bento de FARIA se abeberam as duas correntes opostas, e com carradas de razão. Quer-nos parecer, porém, dadas as premissas estabelecidas; a afirmação de depender exclusivamente da vontade do titular do registro o prolongar a sua eficácia, e as consequências tiradas daquilo que Bento de FARIA denominou "registro novo"; que a opinião deste comercialista se entrosa melhor na doutrina que nega à renovação o caráter de novo registro, do que na que lho dá. Nem se diga que por demais forçamos suas palavras, haja vista o precedente de CARvalHo DE MENdonçA, o qual tendo afirmado estar a renovação "sujeita às mesmas formalidades do registro, depósito e publicidade" (57), sem quebra de coerência, veementemente condenou a doutrina de Carlos da Silva Costa e a interpretação bastarda que às suas palavras se pretendia dar.

Com a exposição da argumentação dos partidários da renovação como novo registro, e a análise do pensar de dois dos maiores comercialistas por eles invocados, estamos aptos a aquilatar, antes mesmo de passar ao estudo da doutrina contrária, a carência de argumentos desta corrente, que, desesperadamente, luta contra o caudal da tradição doutrinária e a jurisprudência de ha muito vigente em nosso país.

(55) Ob. cit., p. 257-258, n. 1.

(56) Ob. cit., p. 261-262, ns. 6 e 7.

(57) “Tratado de Direito Comercial", p. 348, n..$^{\circ} 321$, vol. 5. ${ }^{\circ}$, 1." parte. 
E' acorde a grande maioria dos luminares de nosso direito comercial, em negar à renovação o caráter de um novo registro, e tanto pesa a sua autoridade quanto o valor das ponderações por eles expendidas.

Baseia-se de um modo geral a argumentação desta corrente, na própria essência do direito às marcas, natureza do registro e sua finalidade, direito e finalidade que já analizamos, levando-nos estas considerações a julgar absurda e contrária a todo nosso sistema jurídico a opinião que vê na proteção às marcas um prazo de 15 anos, findo o qual se fará novo registro, sujeito às mesmas formalidades extrínsecas, e consequências intrínsecas, do primitivo registro. Peca esta doutrina contra presupostos básicos de nosso organismo jurídico, contra a própria essência do direito de propriedade e a teoria da prescrição.

Contra tão errônea orientação doutrinária levantaram-se as vozes de Carvalho de Mendonça, Clovis Bevilaqua, Waldemar Ferreira, Gama Cerqueira, Leví Carneiro, Isidoro Campos, e vários outros insignes cultores do direito comercial pátrio:

"Não vemos na renovação do registro da marca uma simples prorrogação do prazo para a proteção desse registro. Essa formalidade aparecenos como meio conservatório de um direito existente sob o pálio da lei" (58). Carvalho de MenDONÇA.

A renovação é permitida "fazer indefinidamente, e não exige mais apreciação do direito à marca, porque este já se acha definitivamente assegurado pelo exame anterior" (59). Clovis BEVILAQUA.

(58) Parecer no caso "Balança Howe", p. 25 de "Renovação do Registro de Marcas", S. Paulo, 1929. Em favor desta asserção invoca IsıDoro Campos a jurisprudência pátria. Cf. Parecer in Apelação n. 6.937, Supremo Tribunal, p. 168, S. Paulo, 1940.

(59) Parecer no caso "Malzbier", p. 141-142, Apelação Cível n. 6.864, Supremo Tribunal, Razões da Ré, Rio, 1938. 
"No processo da renovação do registro da marca não deve e não póde ser admitida nova discussão sobre a legitimidade do registro a renovar, porque se trata, apenas, da prorrogação de um prazo, prestes a vencer-se" (60). Waldemar FerReira.

“O despacho que conceder a renovação não é recorrivel. Não se trata de obter um novo registro, mas apenas de renovar-se um registro definitivamente concedido" (61). Gama Cerqueira.

Leví Carneiro (62), analizando o nosso dispositivo legal, faz uma pergunta à qual dificilmente responderão aqueles que não concebem na renovação o seu carater de mera prorrogação. Diz ele: temos um texto legal dando ao proprietário da marca, decorridos 15 anos, a possibilidade de renovar o registro. Se esta renovação tivesse o mesmo carater que o registro primitivo, porque um texto expresso para dar ao anterior proprietário um direito que a qualquer pessoa cabe? Se a renovação é um novo registro, o anterior proprietário acha-se na situação do individuo que nunca usou da marca e a registra pela primeira vez. Perfeitamente inutil, excrecência inexplicável seria o art. 96 do nosso dec. n. ${ }^{0}$ 16.264. Ora, na lei não se supõe palavras inúteis, quanto mais um artigo inteiro, que desde 1875 encontramos corporificado em nossos textos legais.

A exigência legal da duração limitada dos efeitos do registro não atingiria seu escôpo se não tornasse obrigatória a renovação das formalidades extrínsecas do mesmo. Se assim não se fizesse, para qualquer verificação seria necessário rebuscar os arquivos, por vezes décadas e décadas

(60) Parecer in Ap. n. 6.937. Sup. Trib., Razões da Apelada, p. 126, S. Paulo, 1940.

(61) Ob. cit. p. 337, n. ${ }^{\circ} 238$, II vol.

(62) Parecer in Apelação n. 6.937, Supremo Tribunal, Razões da Apelada, p. 177, S. Paulo, 1940. 
atraz, até encontrar o registro primitivo, inconveniente este que a lei de ha muito procurou sanar (63).

Esta a razão de se renovarem as mencionadas formalidades, em nada ficando prejudicado o direito do titular da marca, anteriormente adquirido e consolidado pelo fluir dos anos.

A PRESCRIÇÃo QUINQUENAL DAS AÇõES PARA PROMOVER A ANULAÇÃO DO REGISTRO DAS MARCAS DE INDÚSTRIA E COMERCIO - O DIREITO ADQUIRIDO AO USO DA MARCA

1. Para termos justa noção do problema em fóco, figuremos a hipótese do comerciante que vai renovar o registro de sua marca, faltando, suponhamos, quatro mezes para que se perfaçam 15 anos de posse pacífica, e ininterrupta utilização da mesma. Estarão prescritas as ações para anular o registro por ele feito, ou cabe novamente a sua oposição? Tem, ou não, ele um direito adquirido sobre a marca renovanda?

Analizaremos a questão sob o prisma variegado da doutrina estrangeira e pátria, e, o que é mais interessante, conforme se trate de marca registrada de acôrdo com a lei, ou em contravenção à mesma.

2. Posição do titular de marca registrada legalmente, ha 15 anos, por ocasiâo da renovação do seu registro.

E' unânime a doutrina alienígena em reconhecer prescritas as ações para anulação do registro, decorrido certo lapso de tempo que varia de país para país, conforme o teor de suas leis.

(63) Neste sentido: Gama Cerqueira, ob. cit. p. 336-337, n. 237, II vol. S. Paulo, 1930, e Parecer in Apelação n. 6.937, Supremo Tribunal, Razões da Apelada, p. 157, S. Paulo, 1940. Cumpre lembrar que no estudo que vimos fazendo temos em vista a "renovação" de marca. Se, na marca renovanda se introduzirem modificações, não se tratará mais de "renovação" de marca anteriormente usada, e sim de registro de nova marca, ao qual em nada se aplicam as considerações que expendemos. 
A razão da prescrição, nesta matéria, é a mesma que rege o instituto quando aplicado aos demais organismos da atividade jurídica. "Pareceu a numerosos legisladores, explicam Braun, Bissot e Favart (64), que haveria perigo em prolongar indefinidamente a incerteza quanto à propriedade das marcas, dando ao primeiro utente o direito de anular em qualquer tempo o registro feito por terceiro, de marca idêntica ou semelhante à sua. Por isso acharam eles prudente decidir que esta ação de anulação prescreveria depois de certo lapso de tempo, a contar do depósito ou registro. Dai, adquirir o registro efeito atributivo após o decurso deste prazo. Neste sistema, o depósito ou registro constitue uma presunção "juris tantum" de propriedade da marca (prova "prima facie", dizem os juristas anglo-saxões), e esta presunção torna-se "juris et de jure" após um período mais ou menos longo".

Do mesmo pensar foi o legislador italiano, quando na recente lei de 1935, evitou que "a declaração de nulidade pendesse perpetuamente, qual espada de Damocles, sobre a cabeça de quem de boa fé fosse titular de u'a marca" (65).

A prescrição, quando aplicada à matéria das marcas, produz, além dos benéficos efeitos que a caraterizam de maneira geral, o particular benefício de pôr termo às exceções de pre-uso "proibição esta cara aos contrafatores", no dizer de Giambrocono e Gozzano (66).

Se tal é a opinião das doutrinas belga e italiana, tambem unívocos são os nossos comercialistas no analizarem o efeito do fluir dos anos na hipótese que estamos examinando. Chamaremos à báila no momento apenas dois escritores, para mais adiante nos determos na análise da opinião dos demais, manifestada em hipótese controversa, na qual se sã̃o favoráveis à inoponibilidade da ação prescrita, $a$ fortiori o serão no caso em apreço.

(64) Ob. cit., pag. 611-612, n. 552.

(65) Sebastianini, ob. cit. p. 97. As condições desta lei, para que se opere a prescrição, segundo o mesmo Autor, são: $a$ ) uso público; $b$ ) bôa fé; $c$ ) decurso de cinco anos; $d$ ) ausência de contestação no decorrer deste período. Cf. ob. cit. loc. cit.

(66) Ob. cit., p. 72-73. 
Campos Birnfeld, em interessante artigo publicado em nossos jornais, teve oportunidade de afirmar: "A aquisição do direito às marcas de fábrica pelo registro, só é perfeita após decorrido o prazo de cinco anos da data do registro, pois nesse caso a prescrição opera em favor do possuidor da marca registrada, atribuindo-lhe o direito de propriedade de fato. Ha dois meios de adquirir o direito às marcas de fábrica: 1 - a prioridade do uso... 2 - a prescrição quinquenal". Sustentar opinião diversa, seria no dizer de Gama Cerqueira, "subverter todos os princípios relativos à prescrição" (67).

Como tivemos oportunidade de observar, o proprietário de marca de indústria ou comércio, que, decorridos 15 anos vái renovar seu registro, é, no sentir unânime da doutrina estrangeira e nacional titular de um direito adquirido, insusceptivel de ser atacado por ações de ha muito prescritas.

Mas, será idêntica a

2. situação do titular de marca ilegalmente registrada, $a b$ initio viciada, que a possue ha 15 anos e promove a renovação de seu registro?

Bem diversa é a hipótese, e o oceano calmo da doutrina comercialista no caso acima analizado, açoitado pelas opiniões as mais controversas, se nos apresenta turbilhonando em vagas desencontradas.

Um dos primeiros e dos mais brilhantes mestres da matéria, Bosro, pontificava no alvorecer do séc. XIX: “Tendo em vista a índole particular da marca, a sua propriedade não se pode adquirir pela prescrição. De fato, para que a possam adquirir com a prescrição é condição essencial que seja legítima a posse...: quod ab initio nullum est, progressu temporis convalescere non potest" (68). Não menos rigoroso é Allart: "Nenhuma proteção poderia ser reconhecida àquilo a que a lei não reconhece existência" (69).

(67) Ob. cit., pag. 338, n. $^{\circ} 238$, nota 1 , II vol.

(68) Ob. cit., p. 369, n. 209.

(69) “Traité de la contrefaçon", p. 169-170, Paris, 1908. 
VIvante, com o peso inegavel da sua autoridade, é incisivo: "A marca que não possue os requisitos exigidos pela lei é nula, absolutamente nula, e qualquer pessoa póde reclamar a nulidade, seja como autor, seja como réu" (70). Di Franco diz não se poder "afirmar extinto um direito que não nasceu" (71), e NAvarRini pondera não poder a lei "de maneira alguma tutelar a má fé do concorrente: e a sua seria verdadeiramente uma concorrência desleal, porque, ainda que se acobertando com o manto da legalidade, teria ela usurpado a outrem os meios de trabalho" (72).

Repercutiu em nosso meio esta doutrina, adotando-a, entre outros, Campos Birnfeld e Carlos da Silva Costa.

O primeiro publicista analiza a hipótese em face do nosso direito: "O caso da renovação de marcas ilegalmente obtidas, porém, não é omisso nem oferece dúvidas: elas foram registradas, em certos casos, contra lei expressa. Os registrantes procuram pelo registro obter a sanção do Govêrno Federal, para um ato de fráude: faltaram à fé cívica. Os registros feitos de má fé não podem atribuir direitos. $\ldots$ Os detentores de marcas ilegalmente registadas deveriam não só perdê-las, como ainda responder por danos causados aos seus verdadeiros proprietários no interregno dos quinze anos durante os quais as usaram e gosaram fraudulentamente". Carlos DA Silva Costa em parecer sobre a controversa questão, afirmou como base de seu sentir o fato de que "contra expressa disposição de lei, a ninguem é lícito adquirir direito" (73).

Dentro do rigor das deduções jurídicas, sedutora se nos afigura a doutrina que vimos expondo. De fato, diz o art. 114 do Dec. $n .^{\circ} 16.264$ :

"ART. 114 - Será nulo o registro de marcas feito contra o que prescreve este regulamento",

(70) Ob. cit. p. 52, n. $887,3 .^{\circ}$ vol.

(71) "Nomi, marchi e segni distintivi di fabbrica", n.o 211, p.

283 do Digesto Italiano, vol. XVI, Turim, 1905-1910.

(72) Ob. cit. p. 56, n. 1.445 , bis, vol. IV.

(73) Sustentação do parecer no caso marca "Radium". 
estabelecendo em seguida, no $\S 10^{\circ}$ a prescrição quinquenal para as ações de nulidade.

Diz mais ainda o mesmo dec. no seu art. 80:

“ART. 80 - Não podem gosar da proteçăo deste regulamento as marcas de indústria e de comércio que contiverem: $1 .^{\circ}, 2 .{ }^{\circ}, 3 .^{\circ}$, etc.".

Argumentamos: como é possivel a um indivíduo prevalecer-se da disposição do $\S 10^{\circ}$ do art. 114 do dec. 16.264, quando este mesmo decreto diz não poder em qualquer dos números do artigo 80, "gosar da proteção deste regulamento" a marca de que ele é titular? A prescrição quinquenal não é um benefício, uma proteção outorgada pelo dec. 16.264? E' lícito a alguem invocar dentro da mesma lei, um texto isolado que lhe é favoravel, fazendo táboa raza de outro que lhe é totalmente adverso?

$\mathrm{E}$, isso tudo, prescindindo do art. 145 do Código Civil, que declara nulo (não anulável) o ato jurídico quando "a lei taxativamente o declarar nulo ou lhe negar efeito" (n. V).

Dentro do rigor exegético e da teoria das nulidades, profundamente sedutora se nos afigura a primeira corrente. Mas, estamos no campo do direito comercial, e teremos ocasião de presenciar a um destes traços caraterísticos deste ramo da ciência jurídica, que traz ao seu estudo o encanto perene da sadia orientação realista de que é dotado.

Com efeito, se nos aferrassemos ao rigor lógico dos conceitos e raciocínios abstratos, sustentando em todas as consequências a bela doutrina acima enunciada, que adviria ao comércio? Juristas, cultores de uma ciência social, colaboradores modestos, mas eficazes, no progresso e prosperidade da comunidade humana, quais seriam as consequências acarretadas pelo seu pensar lógico, escorreito, impecável?

Melhor é dar a palavra àqueles que mais razão têm para a usar: 
- 'lodos esses comerciantes que, ao cabo de longos anos de esforço inteligente e trabalho perseverante lograram constituir um patrimônio valioso nele empregando de par com o esfôrço honesto, largos capitais para a divulgação da marca, em que firmaram as bases da sua riqueza, estão agora sujeitos a verdadeiras disputas que se repetirão periodicamente pondo-lhes em risco o crédito, senão acarretando-lhes a perda total de valores que em face da lei constituem direito adquirido (74).

- Propriedade reconhecida e protegida pela Constituição da República, art. 72, parágrafo 27, a marca de fábrica e de comércio constitue, graças aos vultosos capitais aplicados na propaganda e no aperfeiçoamento de uma indústria, um patrimônio valiosíssimo para o industrial e o comerciante e como tal não poderá ser objeto de disputas reiteradas de 15 em 15 anos, sem graves consequências para a vida, estabilidade e desenvolvimento da indústria e do comércio (75).

Falaram o comércio e a indústria de um Estado de invejavel desenvolvimento econômico. Ouvidas suas palavras, não estranharemos vêr o belo edifício lógico, que ha pouco arquitetavamos, abandonado por juristas da têmpera de Carvalho de Mendonģa, Clovis Bevilaqua, Waldemar Ferreira, Miranda Valverde, Gama Cerqueira, e outros. Nem destôa do parecer insigne destes comercialistas a nossa jurisprudência, judicial e administrativa.

"O titular da marca gosa de um direito adquirido", pontifica Carvalho de Mendonça, “inatacavel, intangivel. Gosou desse direito durante quinze anos, pelo menos; decairam quaisquer reclamações, ainda mais positivas, que

(74) Representação da Associação Comercial de S. Paulo ao Sr. Ministro da Agricultura, p. 212 da Apelação n. ${ }^{\circ}$ 6.937, Supremo Tribunal, Razões da Apelada, S. Paulo, 1940.

(75) Representação do Centro das Indústrias do Estado de S. Paulo ao sr. Ministro da Agricultura, p. 218-219 da Apelação n.? 6.937, Supremo Tribunal, Razões da Apelada, S. Paulo, 1940. 
poderiam ser opostas por ocasião do registo inicial" (76). Clovis Bevilaqua dá-nos o exemplo do jurista exímio que sabe ter na justa medida as realidades sociais, afirmando: "A propriedade industrial da marca está reconhecida e assegurada pelo registro; é direito adquirido. ... Negar a renovação do registro, neste caso, é lesar, conscientemente, o direito alheio, é violar a propriedade do dono da marca, é cometer manifesta ilegalidade" (77).

Não menos luminosa é a lição de Waldemar Ferreira: “Tratava-se de ato jurídico perfeito que, não podendo, nos termos do art. 113, n. 3 da Constituição, ser prejudicado por nenhuma lei, muito menos prejudicado póde ser pelos incumbidos de executá-la. E não sómente de um ato jurídico perfeito se trata, mas tambem de um direito adquirido por via dele" (78). Miranda Valverde em notavel parecer no momentoso caso da marca "Malzbier", afirmou incisivamente: "O registro constitue um direito adquirido" (79). "Decorrido o prazo assinado pela lei para o exercício da ação", ensina Gama Cerqueira, "o registro, qualquer que seja o vício que o inquine, convalesce e a nulidade não poderá ser decretada. A faculdade concedida aos prejudicados de pedirem a anulação do ato decái e este subsiste para todos os efeitos" (80).

Do exposto, podemos concluir que em face da nossa legislação positiva $\left(\S 1 .^{\circ}\right.$ do art. 114 do dec. n. $\left.{ }^{\circ} 16.264\right)$, e

(76) Parecer no caso Balança Howe, p. 26 de Renovação do Registro de Marcas - S. Paulo, 1929. Ainda: Parecer in Apelação n.o 6.937, Sup. Trib., Razões da Apelada, p. 111 - S. Paulo, 1940.

(77) Parecer no caso Balança Howe, p. 20 e 22 de "Renovação do Registro de Marca", S. Paulo, 1929. Em outro parecer, não menos categórico se mostra o eminente mestre: "Prevalece hoje", diz ele, "o prazo único de 5 anos, para todos os casos de nulidade do registro". Cf. Parecer in Apelação n. 6.937, Supremo Tribunal, Razões da Apelada, p. 116, S. Paulo, 1940.

(78) Parecer no caso "Malzbier", n. 10, p. 136 da Apelação Cîvel n. 6.864, Razões da Ré, Rio, 1938.

(79) Parecer cit., p. 167 da Apelação Cível n. 6.864, Razões da Ré, Rio, 1938.

(80) Ob. cit., p. 380, n. $^{\circ} 270$, II vol. 
do ensinamento dos mais lídimos representantes da nossa cultura jurídica, no ramo do direito comercial

o comerciante, decorridos quinze anos, de uso contínuo, utilização efetiva de sua marca, tem direito adquirido à sua renovação.

\section{A OPOSIÇÃO DE TERCEIROS POR OCASIÃo DA RENOVAÇAO DO REGISTRO DA MARCA DE INDÚSTRIA OU COMÉRCIO - O SEU REEXAME PELA ADMINISTRAÇÃO}

1. Poderá o terceiro, titular de direito que deixou prescrever ha já dez anos, opôr-se à renovação do registro? O simples enunciado da questão dispensaria resposta, não fôra a opinião daqueles que vêm na renovação um novo registro. A análise desta corrente doutrinária já a fizemos, pelo que nos deteremos rapidamente no exame desta hipótese, implicitamente solucionada pelas nossas anteriores considerações.

A ponderação das lutas da vida comercial e das qualidades especiais que exige dos indivíduos que a ela se dedicam, nos tirará a primeira impressão, que talvez páire em nosso espírito, de ser a lei neste particular excessivamente rigorosa, estabelecendo a prescrição quinquenal. Já o velho CASAREgis chamava a atenção dos juristas para a caraterística típica dos comerciantes, o serem diligentes e cautelosos: Mercatores solent propria negotia caute et diligenter peragere (81).

Extranhavel é, portanto, que de bôa fé um comerciante deixe prescrever o direito que lhe cabe, para renovar suas pretensões dez anos mais tarde. Extranhavel este fato, a não ser que se explique pela posição atingida pela marca no mercado, pelo valor pecuniário que efetivamente chegou a alcançar, por aquele segundo significado, secondary mea-

(81) Ouro Preto, ob. cit., p. 70, n. 61, nota 21. 
ning, (82) que só o tempo possibilita e que representa de fato uma grandeza econômica, por vezes bastante apetecivel.

Mas, embora a cubiça faça vir água à boca da concorrência desleal, as portas do pretório não lhe são propícias. "A princípio, surgiu a dúvida, em quanto à possibilidade, na renovação das marcas, de se reabrir o debate, relativo à novidade e à legitimidade do primitivo registro, e, após larga controvérsia, se assentou na solução negativa", constata Filadelfo Azevedo (83).

Esta é a nossa orientação jurisprudencial e dela não diverge a doutrina seguida pela maior parte de nossos comercialistas.

Solidonio Leite, em recente parecer, assim externou o seu pensar: "Se alguem pretende ter a prioridade do uso da marca, devia tê-lo provado quando se requereu o registro inicial; ou promover a sua nulidade, dentro do prazo de 5 anos para isso marcado pela lei (84).

E' clara e insofismavel a lição de Waldemar Ferreira: "No processo da renovação do registro de marca não deve e não pode ser admitida nova discussão sobre a legitimidade do registro a renovar" (85). Do mesmo teor são os ensinamentos de Carvalho de Mendonça (85), Levi Carneiro (87), e James Darcy (88), todos eles concordes em não admitir oposição de terceiros no processo da renovação do registro da marca.

(82) Cf. teoria norte-americana do "secondary meaning" das marcas in Giovanni Fontana, ob. cit. p. 63.

(83) Parecer no caso "Malzbier", p. 123 da Apelação Cível n. 6.864, Razões da Ré, Rio, 1938. 1940 .

(84) Apelação n. 6.937, p. 10, Razões da Apelada, São Paulo,

(85) Parecer in Apelação n. $0^{\circ}$ 6.937, Supremo Tribunal, Razões da Apelada, p. 126, S. Paulo, 1940.

(86) Parecer in Apelação n..$^{\circ}$ 6.937, Supremo Tribunal, Razões da Apelada, p. 110, S. Paulo, 1940.

(87) Parecer in Apelação $n .^{\circ}$ 6.937, Supremo Tribunal, Razões da Apelante, p. 179, S. Paulo, 1940.

(88) Parecer no caso "Malzbier”, p. 90, da Apelação Cível n. 6.864, Supremo Tribunal, Razões da Ré, Rio, 1938. 
2. Não só não cabe a terceiros se opôr à renovação do registro, como não póde a administração negar, sponte sua, a renovação, a não ser por falta dos requisitos extrínsecos exigidos pela lei.

E o que afirma, baseado na mais sólida argumentação jurídica, Carvalho de Mendonça: "A repartição da Propriedade Industrial, por ocasião da renovação do registro da marca não tem a faculdade de, sob qualquer pretexto ou motivo, privar o titular dessa marca já registrada do direito de que goza. A lei não lhe confere esse poder" (89).

Gama Cerqueira, analizando as funções da repartição encarregada dos registros, afirmou dever ela se limitar "a verificar e fazer cumprir as formalidades legais extrínsecas, sem entrar no exame das marcas apresentadas, salvo para constatar sua conformidade com a anteriormente registrada" (90).

Desde que o titular da marca renovanda tem sôbre esta um direito adquirido, não cabe evidentemente ao Departamento Nacional da Propriedade Industrial reexaminar o processo do registro, como se se tratasse de registro inicial.

\section{SITUAÇÃO JURfDICA DO POSSUIDOR DE MARCA NAO RENOVADA}

1. A situação do titular de marca de indústria ou comércio, que, terminado o prazo da proteção legal, não renova o registro, tem de ha muito atraido a atenção dos comercialistas.

Pouillet, em sua clássica monografia sobre a matéria, assim se expressa: "A propriedade da marca sobrevive à falta de renovação; o domínio público não tira proveito deste

(89) Parecer no caso Balança Howe, p. 25 de Renovação do Registro de Marcas, S. Paulo, 1929. Em sentido contrário, mas pouco seguido em nossa jurisprudência é o voto vencido de Afonso Costa, adeante transcrito.

(90) Ob. cit. p. 337, n. ${ }^{\circ} 238$, II vol. 
esquecimento. E' ponto sôbre o qual estão de acôrdo todos os comentadores" (91).

Na doutrina belga, Braun, Bissot e Favart defendem a mesma orientação com relação à malfadada lei de 1932: “... as consequências da não renovação se deduzem naturalmente: o direito à marca não sofrerá, mas seu exercício estará suspenso até a regularização do seu estado civil, até que um novo depósito lhe restitua a eficácia" (92). Em outro passo, esclarecem ainda mais a matéria, os mesmos comercialistas: "Pela falta de renovação, não tombava a marca "ipso facto" no domínio público, mas os direitos de seu proprietário ficavam suspensos em relação aos terceiros, até que se fizesse a renovação" (93).

2. Se assim é no direito alienígena, desta saudavel orientação não se aparta o sistema jurídico pátrio.

Com efeito, muitos de nossos homens de leis dão proteção ao titular da marca não renovada, libertando-o da sanha gananciosa da concorrência desleal. Evitam eles o perigo assinalado por Di Franco, de vermos o antigo titular "substituido, no exercício do direito ao uso exclusivo, por qualquer concorrente de má fé, que se lhe adeante a depositar ex novo, por sua conta a marca não mais protegida pela lei" (94).

$\mathrm{Na}$ vigência das leis anteriores ao atual dec. $n .^{\circ}$ 16.264, quasi unânime era o pensar de nossos comercialistas (95).

Almeida Nogueira e Fischer Junior, assim se externavam: "Ainda a respeito destas mesmas marcas dá-se, não a perda delas, mas a das prerrogativas especiais do direito industrial se, expirado o quindecênio do seu registro, não fôr

(91) Ob. cit., p. 180, n. ${ }^{\circ} 131$ bis.

(92) Ob. cit., p. 179, n. 130.

(93) Ob. cit., p. 129, n. 90.

(94) “Digesto Italiano", voc. "Nomi, marchi e segni distintivi di fabbrica", n. ${ }^{\circ} 208$, p. 282. Turim, 1905-1910.

(95) Destôa da voz corrente Ouro Preto, que vê na não renovação, "claramente a intenção de desistir das garantias especiais de que já gosou”. Cf. ob. cit. p. 93, n. 95, nota 4. 
este renovado" (96). Não é diversa a lição de BENTo DE FARIA, para o qual a não renovação "apenas diminuiria os direitos do respectivo titular, isto é, não poderia mais lançar mão da ação criminal contra os contrafatores" (97).

Carvalho de Mendonça, com sua inegavel autoridade se pronuncia, afirmando que: "Os que não renovam o registro ficam na posição dos possuidores de marcas não registradas, isto é, das marcas de fato; as marcas não renovadas perdem sómente a proteção especial, conferida por lei" (98).

Sob o regime inaugurado pelo dec. de 1923 discrepam nossos comercialistas quanto à solução da questão.

Clovis Bevilaqua e Gama Cerqueira divergem do pensamento que vimos analizando, opinando que a não renovação do registro dentro do prazo legal deixa o seu titular na situação de quem vái pela primeira vez registrar a marca (99).

Mais consentânea com nosso sistema jurídico, e com a tutela dos interesses econômicos do comércio, se nos afigura a doutrina sustentada, mesmo em face do decreto vigente, por Waldemar Ferreira, Filadelfo Azevedo e SolidoNIO LEITE.

Waldemar Ferreira, analizando a questão, soluciona-a no direito vigente como a resolvera na legislação anterior Carvalho de Mendonça, fazendo suas as palavras daquele eminente mestre (100).

"A falta de renovação", afirma Filadelfo Azevedo, "si não deixasse o titular de usá-la, não acarretaria perda, sinão para os efeitos penais" (101). Solidonio LeIte é concluden-

(96) Ob. cit. p. $109-110$, n. $^{\circ} 202,10^{\circ}$ vol.

(97) Ob. cit., p. 261-262, n. ${ }^{\circ} 6$.

(98) “Tratado", p. 348, n. ${ }^{\circ} 321,50^{\circ}$ vol. 1. parte.

(99) Clovis Beviluaua, Parecer no caso “Malzbier”, pag. 141142, e 143 da Apelação Cível n. ${ }^{\circ}$ 6.864, Razões da Ré, Rio, 1938. Gama Cerquerra, cit. por Filadelfo Azevedo, Parecer no caso "Malzbier", p. 106-107 da Apelação Cível n.o 6.864, Supremo Tribunal, Razōes da Ré, Rio, 1938.

(100) Parecer no caso Balança Howe, p. 35 de "Renovação do Registro de marca", S. Paulo, 1929.

(101) Parecer no caso "Malzbier", p. 106, Apelação Cível, n.” 6.864, Razões da Ré, Supremo Tribunal, Rio, 1938. 
te em sua apreciação: "a falta de renovação do registro, não faz perder a propriedade, sinão sómente presumir que a marca não continua a ser usada" (102).

Esta nos parece a solução mais adequada e conforme aos princípios gerais normativos da matéria que vimos estudando.

Portanto, ainda em face da lei vigente,

o titular de marca de indústria e comércio que deixa de renovar seu registro, só por isso não decái imediata e irremediavelmente do seu direito $\dot{a}$ mesma.

\section{A RENOVAÇÃo do REgistro E O DIREITo tRansitório}

1. Regem a matéria, de maneira absoluta, os princípios gerais vigentes em direito transitório, quando aplicados à propriedade imaterial, da qual a propriedade industrial é uma das espécies.

E' de se considerar tambem o conceito de direito adqutrido, o qual precisa e sinteticamente foi definido no magnífico "Vocabulaire Juridique" de Henri Capitant: "Direito que o juiz não póde prejudicar, aplicando lei nova" (103).

Ora, tivemos ocasião de observar que em certos casos tem o proprietário da marca direito adquirido sobre a mesma, e uma das hipóteses figuradas foi exatamente a do titular da marca renovanda. Dai o concluirmos não poder este titular ter o seu direito prejudicado pela superveniência da lei nova.

Esta é a doutrina que Ramella (104) esposa, a qual é nitidamente exposta por um dos juristas de maior renome e autoridade em matéria de direito intertemporal e conflito de leis, Roubier. Ensina o insigne mestre francês: "Da mes-

(102) Parecer in Apelação n. 6.937, Razões da Apelada, Supremo Tribunal, p. 8, S. Paulo, 1940.

(103) Voc. "Droit acquis", p. 208, Paris, 1936.

(104) Ob. cit. p. 11, n. $424,2 .^{\circ}$ vol. 
ma maneira, para a aquisição (ou extinção) dos direitos intelectuais é competente a lei em vigor ao tempo do fato considerado como aquisitivo (ou extintivo)" (105). E, tornando ainda mais claro o seu pensar, exemplifica com as marcas de indústria ou comércio.

2. Entre nós, diverge da doutrina seguida pela grande maioria dos juristas pátrios Mendes Pimentel, sustentando que, embora intangivel a marca durante o prazo da proteção legal, ficará o direito de seu titular subordinado à lei nova quando por ocasião da renovação (106).

Não seguem esta opinião, nem a nossa doutrina, nem a jurisprudência.

Waldemar Ferreira, afirmou categoricamente tratar-se, no caso, de um "ato jurídico perfeito", que não pode "nos termos do art. 113, n. ${ }^{\circ} 3$, da Constituição, ser prejudicado por nenhuma lei" (107), e a sua asserção é corroborada por vários comercialistas. Carvalho de MendonçA teve oportunidade de ressaltar o carater de "propriedade intangível" (108) deste direito do titular do registro renovando, enquanto Mranda Valverde explicitamente afirma: “quaisquer alterações, que as leis posteriores houvessem estatuido para o registro de marcas de indústria ou de comércio, não poderiam invalidar as marcas registradas na vigência das leis depois modificadas. O registro constitue um direito adquirido, insusceptivel, por tanto, de ser menosprezado com as leis ulteriores" (109). 1933.

(105) Conflits de Lois, p. 200, n. 97, nota 1, 2. vol., Paris,

(106) Cf. Barros Barreto, sentença no caso Braga \& Wblman V. Abel Rodrigues \& Cia., in "Arquivo Judiciário", p. 123, vol. 23, 1932.

(107) Parecer no caso "Malzbier" n. 10, p. 136, Apelação Cível n. 6.864, Razões da Ré, Rio, 1938.

(108) Parecer in Apelação n. ${ }^{\circ}$ 6.937, Supremo Tribunal, Razões da Apelada, p. 110, S. Paulo, 1940.

(109) Parecer no caso "Malzbier" p. 167, Apelação Cível n. 6.864, Supremo Tribunal, Razões da Ré, Rio, 1938. 
Campos Birnfeld, estudando a questão, diz ter sido esta a orientação seguida pelo nosso extinto Congresso, o qual julgava lhe assistir "o direito de alterar ou modificar o regime da propriedade das marcas, regulando-a de tempo em tempo, embora não possa retroagir no tempo nem alterar os direitos adquiridos ex-vi das leis anteriores" (110).

Ainda hoje, esta é a orientação da nossa doutrina e legislação, consentânea com a tradição jurídica pátria e com os sãos princípios informadores da ciência alienígena.

Portanto,

rege o direito ḋ marca a lei vigente ao tempo de seu título aquisitivo, isto é, vigente ao tempo do primeiro registro.

\section{A RENOVAÇÃO DO REGISTRO DAS MARCAS INTERNACIONAIS.}

A renovação do registro das marcas que gozam de proteção internacional, feito no Departamento Internacional para Proteção da Propriedade Industrial, em Berna, rege-se pelo disposto nas convenções internacionais, não apresentando o seu processo peculiaridades dignas de nota sob o ponto de vista da doutrina jurídica do instituto que vimos estudando.

Apenas convém assinalar a mais intensa repressão à fraude e má fé, estatuida expressamente no artigo $6 .^{\circ}$ bis da Convenção da União de Paris, revista em Háia, em 1925:

"Não será fixado prazo para se reclamar a: anulação das marcas de má fé".

Facil é compreender o alcance deste dispositivo, plenamente justificavel no âmbito do comércio internacional, muito mais propício à rapinagem da concorrência desleal do que o estreito campo dos territórios nacionais.

(110) Artigo sob título "As marcas de fábrica". 
Ressaltada esta particularidade, podemos afirmar processar-se a renovação das marcas internacionais de um modo geral sob a égide dos mesmos princípios jurídicos que vimos analizando, modificados apenas em minúcias que não lhes altera a fisionomia geral.

São Paulo, 25 de Julho de 1942. 